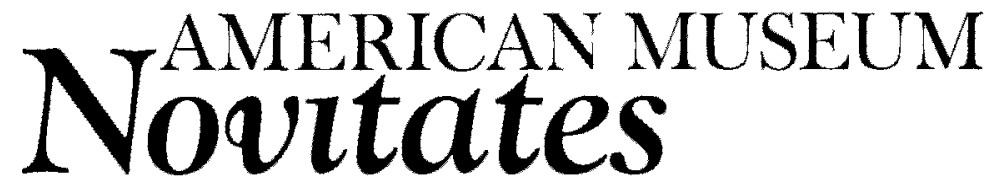

PUBLISHED BY THE AMERICAN MUSEUM OF NATURAL HISTORY CENTRAL PARK WEST AT 79TH STREET, NEW YORK, NY 10024 Number 3542, 18 pp., 9 figures, 3 tables

December 7, 2006

\title{
Anatomy of Disguise: Camouflaging Structures in Nymphs of Some Reduviidae (Heteroptera)
}

\author{
CHRISTIANE WEIRAUCH ${ }^{1}$
}

\begin{abstract}
Immature stages of Reduvius personatus (Linnaeus) and some other Reduviidae are known to camouflage themselves with a range of materials found in their environment. Even though this behavior has been observed in several species, camouflaging structures have never been studied in a comparative way. This study documents for the first time the structure that is involved in the application of camouflaging material, i.e., the hind tarsal fan, and reveals structures that assure the fastening of the camouflaging material, i.e., anchor setae and trichomes, in eight species representing five subfamilies of Reduviidae. Whereas anchor setae assure the attachment of camouflaging material by their mechanical properties, short-projection trichomes, long-projection trichomes, and grouped trichomes are here proposed to secrete a sticky substance for this purpose. Primary homology hypotheses on the three types of trichomes are proposed. At least in some species, short-projection trichomes appear to be responsible for the fastening of the camouflaging layer close to the integument, whereas long-projection trichomes may hold the outer layer of camouflaging material in place.
\end{abstract}

\section{INTRODUCTION}

Immature stages of the predatory assassin bug Reduvius personatus (Linnaeus, 1758), the "masked hunter", have attracted the attention of entomologists since their first description almost 250 years ago. The most remarkable feature of these nymphs is a behavior that is known in only few insects and is best documented in the neuropteran Chrysopidae family (Eisner et al., 1978; Stitz 1931): the nymphs camouflage themselves with a range of materials found in their environment. This behavior is accurately reflected in the name of Reduvius personatus: Fabricius' (1775) generic name Reduvius is derived from the Latin noun reduvia meaning "remainder or fragment", and Linnaeus's (1758) epithet, the Latin adjective personatus, meaning "masked".

\footnotetext{
${ }^{1}$ Division of Invertebrate Zoology, American Museum of Natural History (weirauch@amnh.org).
} 
The camouflage cover of $R$. personatus often consists of fine soil or wood dust, which transforms the insect into a small walking pile of debris. The benefit for the nymph of $R$. personatus may be twofold, since the camouflaged nymph might be less perceptible to potential predators, but the little predator might also have an advantage in stalking its own prey (Harz, 1952).

Camouflaging in nymphs of $R$. personatusa behavior absent in the adult - was initially thought to be a passive process, i.e., the nymphs were getting dirty merely because of the habitat they live in, as indicated by Fabre (1903) in his Souvenirs Entomologiques. However, Weber (1930) and Immel (1955) observed that nymphs throw substrate particles on the dorsum using their hind legs and that the cover is replaced after each moult. Dispons (1955), who referred to the camouflaging behavior as "prosoponie", after the Greek word for "mask", gave a detailed account of the behavior for Reduvius personatus.

Structures that assist in throwing substrate particles on the dorsum other than the hindlegs themselves - in the following referred to as "application structures"- have never been discussed for Reduvius personatus. The structures that fasten substrate particles on the nymphs' integument, here called fastening structures, were likewise not studied in detail: Weber (1930) claimed that "erect setation" on the integument accounted for the fastening. Madel (1951) and Immel (1955) argued that substrate particles were held in place by short thornlike and apically curved microtrichia, which are abundant on the dorsum of nymphs of $R$. personatus. Fabre (1903) and Miller (1956) believed that glandular secretions or even glandular hairs were responsible for the fastening of camouflaging material, but they did not document such secretions or hairs.

Nymphal camouflaging behavior is not restricted to $R$. personatus among Reduviinae, but is known for species of Acanthaspis Amyot and Serville (Brandt and Mahsberg, 2002; Ambrose, 1999; Louis, 1974; Miller, 1953; Odhiambo, 1958; Villiers, 1948; Butler, 1923), Alloeocranum Reuter (Ambrose, 1999), Edocla Stål (Ambrose, 1999), Empyrocoris Miller (Ambrose, 1999), Holotrichius Burmeister
(Kott, 2001; Dispons, 1955), Leogorrus (Lent and Wygodzinsky, 1979), Paredocla Jeannel (Brandt and Mahsberg, 2002; Villiers, 1948), Tetroxia Amyot and Serville (Louis, 1974), and species of Reduvius other than $R$. personatus (Dispons, 1955; Miller, 1953; Wygodzinsky and Usinger, 1946). In addition, camouflaging is not restricted to nymphs of Reduviinae, but also occurs in nymphs of Cetherinae (Louis, 1974), Salyavatinae (Ambrose, 1999; McMahan, 1982, 1983a, 1983b; Miller, 1953), Stenopodainae (Readio, 1927; Breddin, 1904), and Triatominae (Ambrose, 1999; Zeledón et al., 1973; Hase, 1940; Breddin, 1904). Cai et al. (2002) provided a literature summary on camouflaging in several species of Reduviidae. Many of these descriptions state that camouflaging is an active process during which the hind legs gather and apply camouflaging material (e.g., Kott, 2001; McMahan, 1982; Louis, 1974; Dispons, 1955; Hase, 1940). As for $R$. personatus, all of the above studies lack detailed examination of the hind legs that may reveal application structures.

As to the camouflaging cover, it becomes clear from the above-mentioned references that two types or layers of camouflaging material are often distinguishable. The first layer is close to the integument, consists of small soil and substrate particles, and is referred to as "natural camouflaging" (Ambrose, 1999) or "dust coat" (Brand and Mahsberg, 2002) by recent authors. Judging from the literature, this dust-coat camouflaging seems to be present in all reduviid nymphs that exhibit camouflaging. The second layer is farther removed from the body and may consist of coarser particles, but also corpses of insects the reduviid nymph has fed on. This outer layer is called "corpse camouflaging" by Ambrose (1999) or "backpack" by Brand and Mahsberg (2002). Corpse camouflaging is known for several species of Acanthaspis (Ambrose, 1999; Louis, 1974; Odhiambo, 1958), and for one species each of Edocla (Ambrose 1999) and Paredocla (Brand and Mahsberg, 2002). Brandt and Mahsberg (2002) demonstrated for a species of Paredocla that the corpse cover is important as protection from potential predators, whereas the dust cover may play a role in aggressive mimicry towards their ant prey. 
Even though some of the authors who described camouflaging in reduviid nymphs explained how camouflaging material was fastened to the integument, illustrations of fastening structures are limited to one line drawing for Acanthaspis vitticollis by Louis (1974). No study so far has approached the fastening structures from a comparative perspective, nor has any consideration been given to the fact that many species seem to apply two layers of camouflaging material.

The present study aims to document application and fastening structures involved in camouflaging behavior in a sample of nymphs of Reduviidae using light and scanning electron microscopy. Through its comparative approach, this study will assist in establishing a terminological framework for the description of camouflaging structures and will help to gain insights into their potential homologies.

\section{MATERIAL AND METHODS}

Nymphs of eleven species of Reduviidae representing eight subfamilies were examined in this study using light microscopy and scanning electron microscopy. For six of these species in the subfamilies Reduviinae, Salyavatinae, and Triatominae, camouflaging behavior was previously reported. For the remaining five species in the subfamilies Cetherinae, Hammacerinae, Harpactorinae, Peiratinae, Reduviinae, and Sphaeridopinae, evidence of camouflaging behavior or behavior of nymphs in general is absent in the literature. Examination of these species may reveal camouflaging structures, and may thus predict if camouflaging behavior could occur.

Two aspects determined the choice of taxa studied. First, immatures are collected rather infrequently and-unless they are associated with adults - it is often impossible to identify them even to generic level. The availability of material is therefore limited. Secondly, the species or genera were chosen to represent the widest possible range of subfamilies.

Light Microscopy (LM): To examine different layers of camouflaging material on the integument, a living 4th instar nymph of Reduvius personatus was partly dismantled with fine forceps and observed using a Wild
Heerbrugg 307800 stereomicroscope. For more detailed light microscopic observation, the abdominal tergites and part of the pronotum were removed and macerated in warm $\mathrm{KOH}$ (approximately 10\%) for approximately four hours. After washing with 70\% alcohol and staining with Chlorazol Black E, pieces of integument were set up for observation on a slide in glycerin and examined using either a Leitz Diaplan, Zeiss Axioplan (Freie Universität Berlin) or a Nikon Eclipse 80i (American Museum of Natural History) compound microscope. Photographs were taken with a Fujifilm FinePix S1 Pro digital camera on the Zeiss Axioplan microscope.

SCANNing Electron Microscopy (SEM): Specimens were dissected and macerated as described for light microscopic observation. Pieces of integument were dehydrated (alcohol 80\%, 95\%, absolute alcohol), coated on a Balzers Union SCD 014 (Freie Universität Berlin) or Denton Vacuum DeskII (American Museum of Natural History), and observed on a Philips SEM 515 (Freie Universität Berlin) or a Hitachi S-4700 (American Museum of Natural History).

TERMINOLOGY: The terminology of glandular structures follows Farine (1987) and Noirot and Quennedey (1991). Sclerotized elements of a glandular unit are referred to as ductule or efferent duct, and comprise a receiving canal, a saccule, and a conducting canal, all of which are observable after maceration of the glandular unit.

I use the term trichome to describe a composite structure comprising a hairlike portion on the outer surface of the cuticle, which is associated with a glandular unit on the inside of the cuticle. The term is used in plant morphology, but also in entomology, where it refers to a glandular hair, most commonly one that exudes a secretion attractive to ants (Nichols, 1989).

AbBreviations: aset, anchor setae; cc, conducting canal of a ductule; du, ductule (efferent duct, i.e., the sclerotized elements) of a glandular unit; gtp, grouped trichome projection; gtsac, grouped trichome saccule; htf, hind tarsal fan; ltp, long trichome projection; Itsac, long-projection trichome saccule; ma, muscle attachment; po, pore of trichome or glandular unit; rec, receiving canal of ductule; 
rptp, rosettelike trichome projection; sac, saccule of a ductule; set, seta; sp1, abdominal spiracle 1; splat, sclerotized plate on abdominal tergites; stp, short trichome projection; stsac, short-projection trichome saccule; t1-t4, abdominal tergites 1-4; tar3, tarsomere three.

Material: Specimens studied belong to the American Museum of Natural History $(\mathrm{AMNH})$; were donated to the author by Ralf Britz (Microtomus sp.), Peter Kott (Holotrichius tenebrosus) or Walter Sudhaus (Reduvius personatus); or were collected by the author (Peirates sp.; Rhynocoris erythropus). A determination to species level of nymphs not associated with adult specimens can be provided for only some of the taxa examined since immatures are undescribed for most species of Reduviidae. Unless otherwise stated, the specimens were identified to species or generic level by the author. Cetherinae: Eupheno sp., 4th instar, Misiones, Argentina (AMNH). Hammacerinae: Microtomus sp., 3rd instar, USA, Florida, spring 2002, leg. R. Britz. Harpactorinae: Rhynocoris erythropus, 3rd instar, France, Nimes, May 1999, leg. C. Weirauch. Peiratinae: Peirates sp., 3rd instar, Australia, Queensland, Bald Rock, June 1996, leg. C. Weirauch. Reduviinae: Acanthaspis sp., 3rd instar, India, South India: Coimbatore District, Marudamalar Hills, $1800 \mathrm{ft}$., Oct. 1969, leg. P. S. Nathan (AMNH); 4th instar, Myanmar, February 1996, leg. C. Weirauch. Holotrichius tenebrosus, instars 1-5, lab culture from P. Kott, det. P. Kott. Leogorrus sp., 4th instar, Trinidad, W. I., Arima Valley, 800-1200 ft., Feb. 10-22, 1964, det. P. Wygodzinsky. Reduvius personatus, 4th instar, USA, New Mexico, leg. W. Sudhaus. Salyavatinae: Salyavata sp., 5th instar, Guatemala, Tikal, Dec. 29, 1973, leg. D. H., A. C., and K. M. C. Mistner, ex termite nest T 820 (AMNH). Sphaeridopinae: Sphaeridops sp., 5th instar, [no locality label] (AMNH). Triatominae: Triatoma vitticeps, 3rd instar, [no locality label], det. P. Wygodzinsky (AMNH).

\section{RESULTS}

The present study documents that immature stages of certain Reduviidae (fig. 1) possess a range of specialized structures, which supposedly assist in applying and fastening the camouflaging material used by these predators for their disguise (figs. 2-9). According to their functions, i.e., application versus fastening of camouflaging material, camouflaging structures are here divided into two groups.

All species examined for which camouflaging behavior was previously known were found to possess specialized camouflaging structures (table 1). This is true for Acanthaspis sp., Holotrichius tenebrosus, Leogorrus sp., and Reduvius personatus (Reduviinae); Salyavata sp. (Salyavatinae); and Triatoma vitticeps (Triatominae). Features that almost certainly represent camouflaging structures were also found in two species for which no biological data on immature stages exist, Eupheno sp. (Cetherinae) and Sphaeridops sp. (Sphaeridopinae). No camouflaging structures were found in Microtomus sp. (Hammacerinae), Rhynocoris erythropus (Harpactorinae), and Peirates sp. (Peiratinae), for which camouflaging behavior has never been reported.

\section{Application Structure: Hind Tarsal Fan}

An application structure is located on the hind tarsus of the nymph of some species. It is formed by a fanlike arrangement of long, fine setae on the dorsoposterior margin of the distal tarsomere (fig. 6E) and is here referred to as hind tarsal fan. Among the Reduviinae observed in this study, Acanthaspis sp., Leogorrus sp., and Reduvius personatus (fig. 6E) possess a well-developed hind tarsal fan. This fan is also present in the species of Triatominae examined here, Triatoma vitticeps. In addition, the hind tarsal fan has previously been described as "numerous very long and delicate hairs", making it a character of taxonomic and possibly group-defining importance in nymphs of numerous species of Triatominae (Lent and Wygodzinsky, 1979), but no reference was made to the potential involvement of this structure in camouflaging behavior. Table 2 combines results from Zeledón et al. (1973) and Lent and Wygodzinsky (1979) and shows eleven species of Triatominae, for which both camouflaging habits and presence/absence of the hind tarsal fan are known. In these eleven species, presence of camouflaging behavior correlates with the presence of the hind tarsal 


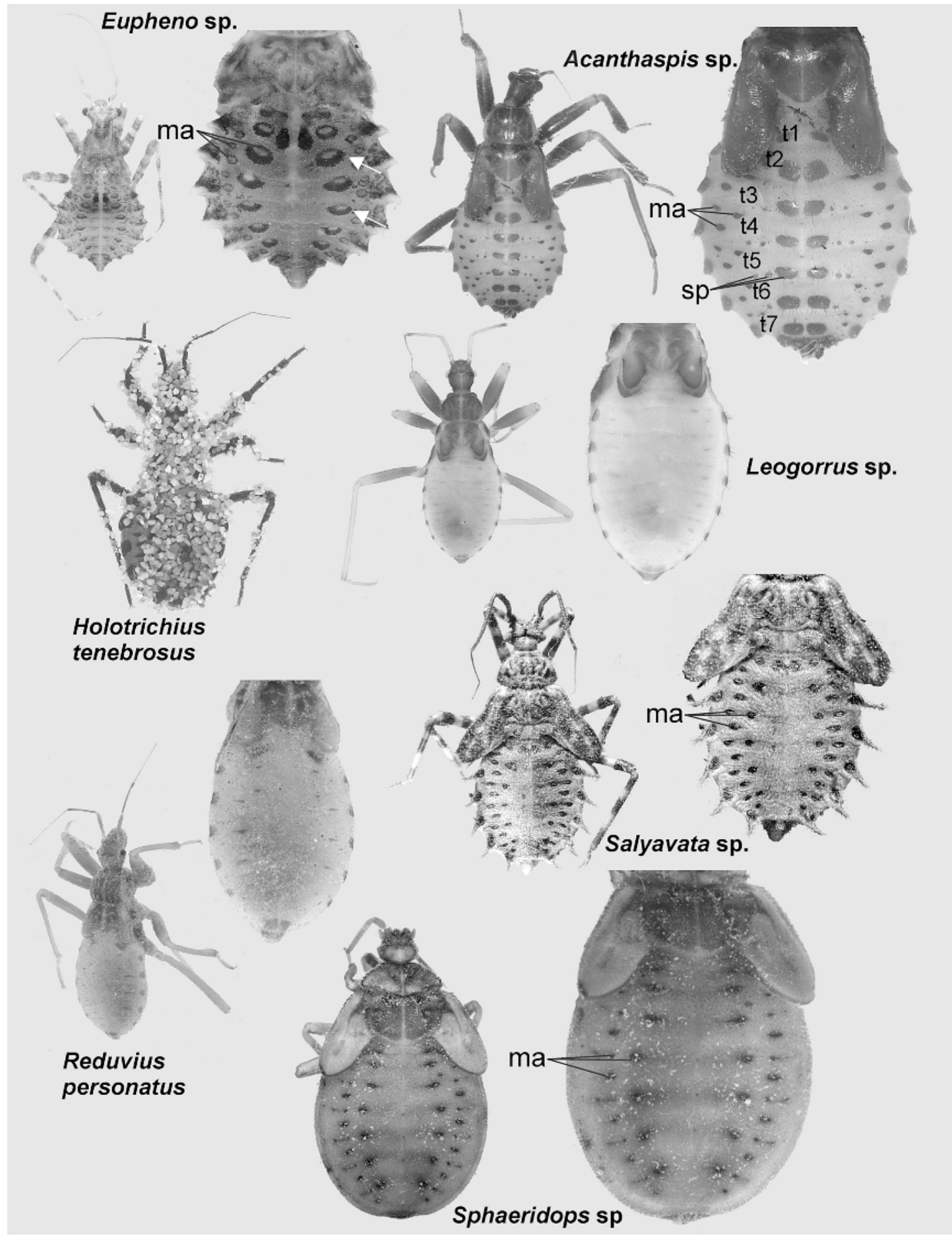

Fig. 1. Habitus and dorsal view of abdominal tergites of reduviid nymphs that possess camouflaging structures. Only Holotrichius tenebrosus is shown in camouflaged condition, the other species are cleaned. 
TABLE 1

Nymphal Instar, Presence and Absence of Hind Tarsal Fan, Trichomes, and Indication of Camouflaging Literature for Taxa of Reduviidae Examined for Camouflaging Structures

\begin{tabular}{|c|c|c|c|c|c|c|}
\hline Subfamily & Genus/species & Instar & $\begin{array}{l}\text { Hind tarsal } \\
\text { fan }\end{array}$ & $\begin{array}{l}\text { Trichomes } \\
\text { (gland + hair) }\end{array}$ & $\begin{array}{c}\text { Behavior } \\
\text { previously } \\
\text { documented }\end{array}$ & Citation \\
\hline Cetherinae & Eupheno sp. & 4 & absent & present & no & $\begin{array}{l}\text { Louis (1974) } \\
\text { documented for } \\
\text { closely related } \\
\text { Cethera spp. }\end{array}$ \\
\hline Hammacerinae & Microtomus sp. & 3 & absent & absent & no & \\
\hline Harpactorinae & Rhynocoris erythropus & 3 & absent & absent & no & \\
\hline Peiratinae & Peirates sp. & 3 & absent & absent & no & \\
\hline \multirow[t]{4}{*}{ Reduviinae } & Acanthaspis sp. & 5 & present & present & yes & $\begin{array}{l}\text { Miller 1956, Odhiambo } \\
\text { 1958, Louis 1974, } \\
\text { Brandt and } \\
\text { Mahsberg } 2002\end{array}$ \\
\hline & Holotrichius tenebrosus & 5 & absent & present & yes & $\begin{array}{l}\text { Dispons } 1955, \text { Kott } \\
2001\end{array}$ \\
\hline & Leogorrus sp. & 4 & present & present & yes & $\begin{array}{l}\text { Lent and Wygodzinsky } \\
1979\end{array}$ \\
\hline & Reduvius personatus & 4 & present & present & yes & $\begin{array}{l}\text { Weber 1930, Madel } \\
\text { 1951, Immel } 1955\end{array}$ \\
\hline Salyavatinae & Salyavata sp. & 5 & absent & present & yes & McMahan 1982, 1983 \\
\hline Sphaeridopinae & Sphaeridops sp. & 5 & absent & present & no & \\
\hline Triatominae & Triatoma vitticeps & 3 & present & $\begin{array}{r}\text { gland present, } \\
\text { hair absent }\end{array}$ & yes & Zeledon et al. 1973 \\
\hline
\end{tabular}

fan and absence of camouflaging behavior with absence of the fan.

Among the species that possess fastening structures (discussed below), Eupheno sp. (Cetherinae), Holotrichius tenebrosus (Redu-

TABLE 2

Hind Tarsal Fan and Camouflaging Behavior in Eleven Species of Triatominae According to Lent and Wygodzinsky (1979) and Zeledón et al. (1973)

\begin{tabular}{|c|c|c|}
\hline & $\begin{array}{l}\text { Hind tarsal } \\
\text { fan }\end{array}$ & $\begin{array}{c}\text { Camouflaging } \\
\text { behavior }\end{array}$ \\
\hline $\begin{array}{l}\text { Dipetalogaster } \\
\quad \text { maximus }\end{array}$ & present & present \\
\hline Panstrongylus herreri & present & present \\
\hline P. megistus & present & present \\
\hline Rhodnius prolixus & absent & absent \\
\hline Triatoma barberi & absent & absent \\
\hline T. infestans & present & present \\
\hline T. lenti & present & present \\
\hline T. maculata & present & present \\
\hline $\begin{array}{l}\text { T. protracta } \\
\text { navajoensis }\end{array}$ & absent & absent \\
\hline T. spinolai & present & present \\
\hline T. vitticeps & present & present \\
\hline
\end{tabular}

viinae), Salyavata sp. (Salyavatinae), and Sphaeridops sp. (Sphaeridopinae) lack a hind tarsal fan. In $H$. tenebrosus, the fan is absent not only in the 5th instar, as indicated in table 1 , but in all five instars studied. The hind tarsal fan is also absent in the threes species that lack fastening structures for camouflage (discussed below), Microtomus sp. (Hammacerinae), Rhynocoris erythropus (Harpactorinae), and Peirates sp. (Peiratinae).

The ventral surface of the distal tarsomere of Reduvius personatus is densely covered with setae (fig. 6F). Some of these setae are considerably stouter than the rest and have a serrated ventral surface. Possibly, these setae assist in loosening camouflaging particles from the substrate.

Fastening Structures: Anchor Setae and TRICHOMES

Once the substrate particles have been applied to the abdominal and thoracic tergites, a second set of structures assures their fastening. Two structural types of fastening 


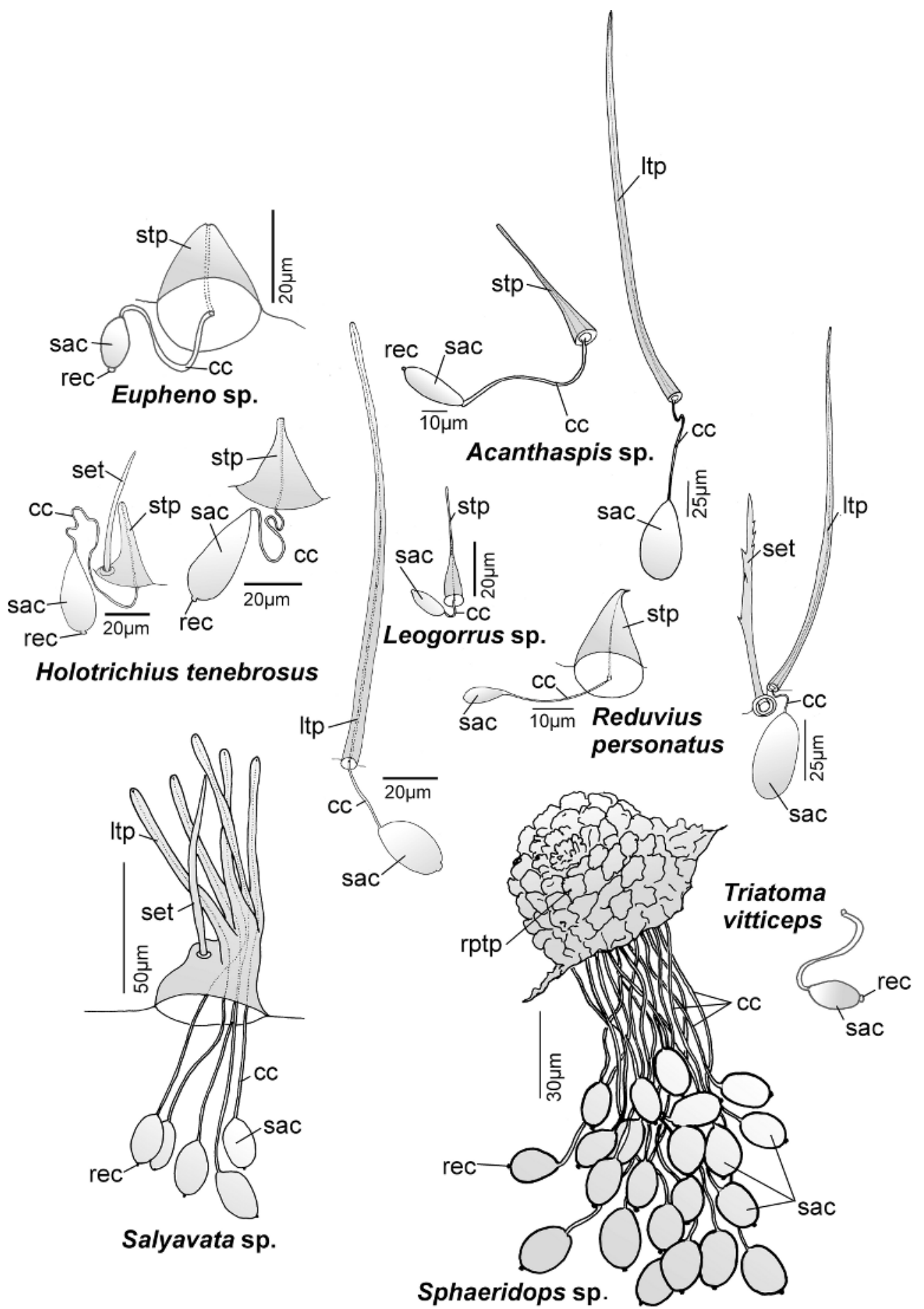

Fig. 2. Long-projection trichomes, short-projection trichomes, and grouped trichomes in nymphs of Reduviidae in the subfamilies Cetherinae, Reduviinae, Salyavatinae, Sphaeridopinae, and Triatominae. 


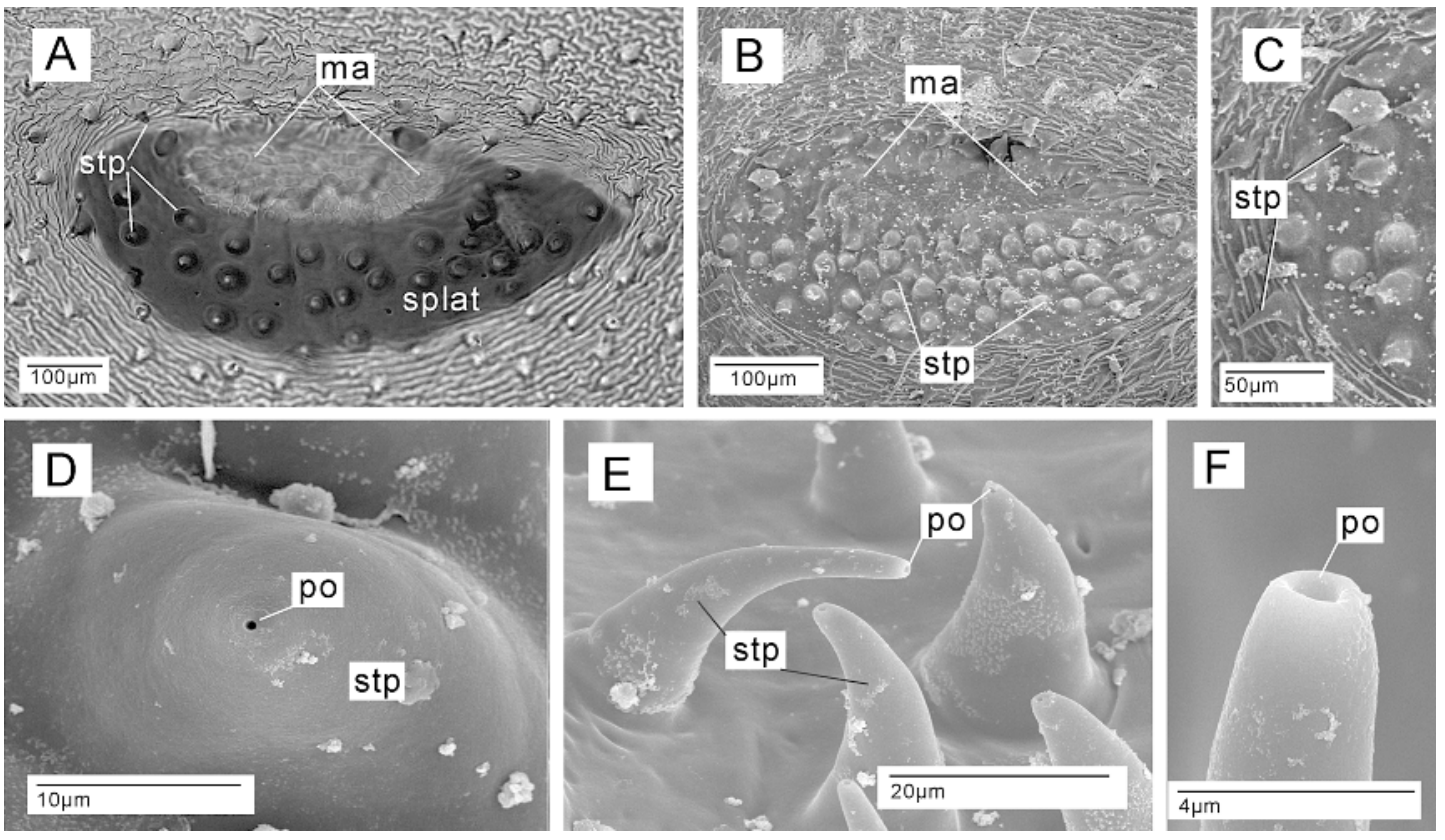

Fig. 3. Eupheno sp. (Cetherinae): Camouflaging structures on the abdominal tergites in the 4th instar nymph. A. Sclerotized plate surrounded by membrane, showing short-projection trichomes, LM. B. Sclerotized plate surrounded by membrane, showing short-projection trichomes, SEM. C. Close-up of part of $\mathrm{B}$, showing margin of sclerotized plate with variously shaped short-projection trichomes. D. Tubercleshaped short-projection trichome. E. Spinelike short-projection trichomes. F. Pore of a spinelike shortprojection trichome.

structures were found in this study, one formed by setae, the other by trichomes. The setal fastening mechanism appears to be purely mechanical in that it holds the camouflaging material with the anchor-shaped tip of the seta. This type is here referred to as anchor seta and was found only in specimens belonging to the genus Acanthaspis (Reduviinae) (figs. 4B, C, E). A second type of fastening structure is also present in Acanthaspis: it comprises a glandular unit that is associated with a hairlike projection, which serves as excretory structure of the glandular unit. This composite structure is here referred to as trichome (figs. 2, 4B-G). The ductules of the glandular units (figs. 4F, G) together with the external projections (figs. 4B-D) of these trichomes may be observed with light (fig. 4F) or electron microscopy (fig. 4G) even in macerated specimens, in which the gland cells were destroyed. Presumably, the fluid secreted by this trichome is sticky and thus holds the camouflaging particles in place.
Trichomes were found in all species that were previously reported to possess camouflaging behavior (table 1) with the exception of Triatoma vitticeps. In this species, although glandular units are present, they do not open through a hairlike projection but directly onto the exterior surface of the integument (fig. 2). Trichomes were also found in Eupheno sp. (Cetherinae) and Sphaeridops sp. (Sphaeridopinae), two of the five species examined, for which camouflaging behavior was previously undocumented. No fastening structures were found in the remaining three species, for which indication of camouflaging is lacking, Microtomus sp. (Hammacerinae), Rhynocoris erythropus (Harpactorinae), and Peirates sp. (Peiratinae) (table 1).

The trichomes found in this study show substantial variation between taxa (table 3 ). In addition, more than one type of trichome may be present in a single species (figs. 2, 6A, $7 \mathrm{~B}, \mathrm{D}, 8,9 \mathrm{~A}, \mathrm{D})$. The trichomes on the abdomen (or on abdomen and thorax in some 

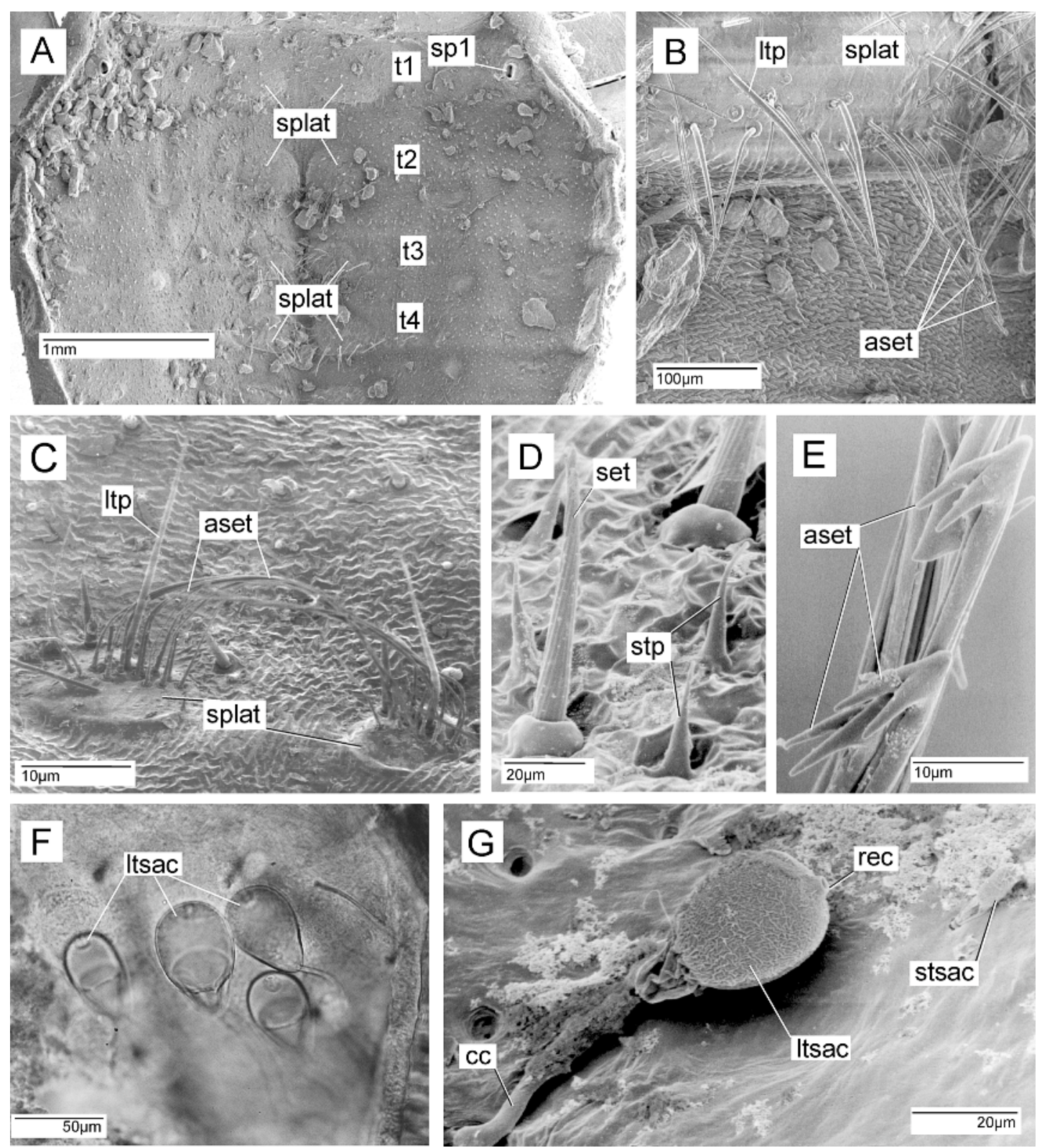

Fig. 4. Acanthaspis sp. (Reduviinae): Camouflaging structures on the abdominal tergites in the 5th instar nymph, A-E external views, F, G, internal views. A. Tergites with median sclerotized plates as seen in the SEM. B. Posterior margin of one of the median sclerotized plate with hairlike long-projection trichomes and anchor setae. C. Two lateral sclerotized plates with long-projection trichomes and anchor setae. D. Spinelike short-projection trichomes. E. Apex of anchor setae. F. Ductules of long-projection trichomes, light microscope. G. Ductule of one long-projection trichome and one short-projection trichome, SEM.

instances) are described briefly for each species in the following (table 3 ). The trichomes are characterized according to the length and shape of their external projections, size and shape of the internal saccules, and arrangement of trichomes. Three types of trichomes (short-projection trichome, longprojection trichome, and grouped trichome) 

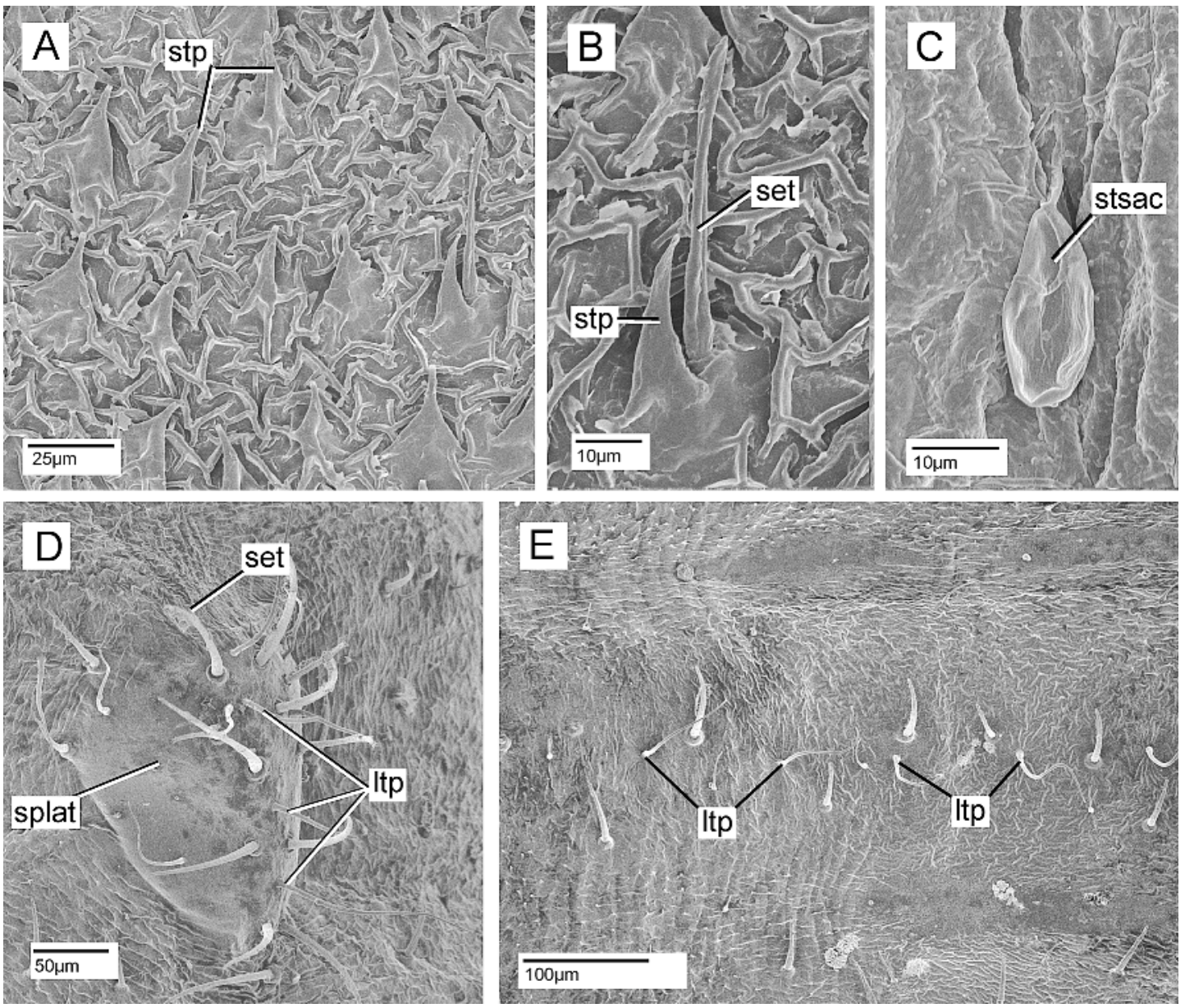

Fig. 5. Holotrichius tenebrosus and Leogorrus sp. (Reduviinae): Camouflaging structures on the abdominal tergites of one 5th instar nymph of $H$. tenebrosus (A-C) and one fourth instar nymph of Leogorrus sp. (D, E), all external views except C (internal view). A. Trichomes that may represent shortprojection trichomes. B. Close-up of one trichome associated with a seta. C. Ductule of one trichome. D. Lateral sclerotized plate with hairlike long-projection trichomes and setae. E. Posterior margin of abdominal tergite showing transverse row of long-projection trichomes and setae.

are distinguished, which are here treated as potential primary homologous structures.

Eupheno sp. (figs. 1-3): Abdomen with only one type of trichome, trichome with short projection, no grouped trichomes. Projection either shaped into low tubercle (fig. 3D) or spine (fig. 3E, F). Low tubercles only in areas adjacent to the sclerotized plates, which serve as points for muscle insertions (fig. 1, white arrows; fig. 3A, B). Spines distributed over the tergites (fig. 3A). Saccules elliptical $(1=$ approximately $10 \mu \mathrm{m}$ ).
Acanthaspis sp. (figs. 1, 2, 4): Trichomes with short projections and with long projections on abdomen, no grouped trichomes. Short-projection trichomes with slender spinelike projections (fig. 4D) and elliptical saccules $(1=$ approximate $30 \mu \mathrm{m})$ (fig. FG). Shortprojection trichomes evenly distributed on the abdominal tergites. Long-projection trichomes with very long, slender, hairlike projections and elliptical saccules $(1=$ approximately $40 \mu \mathrm{m}$ ) (figs. 4B, C, F, G). Long-projection trichomes on abdominal tergites largely re- 


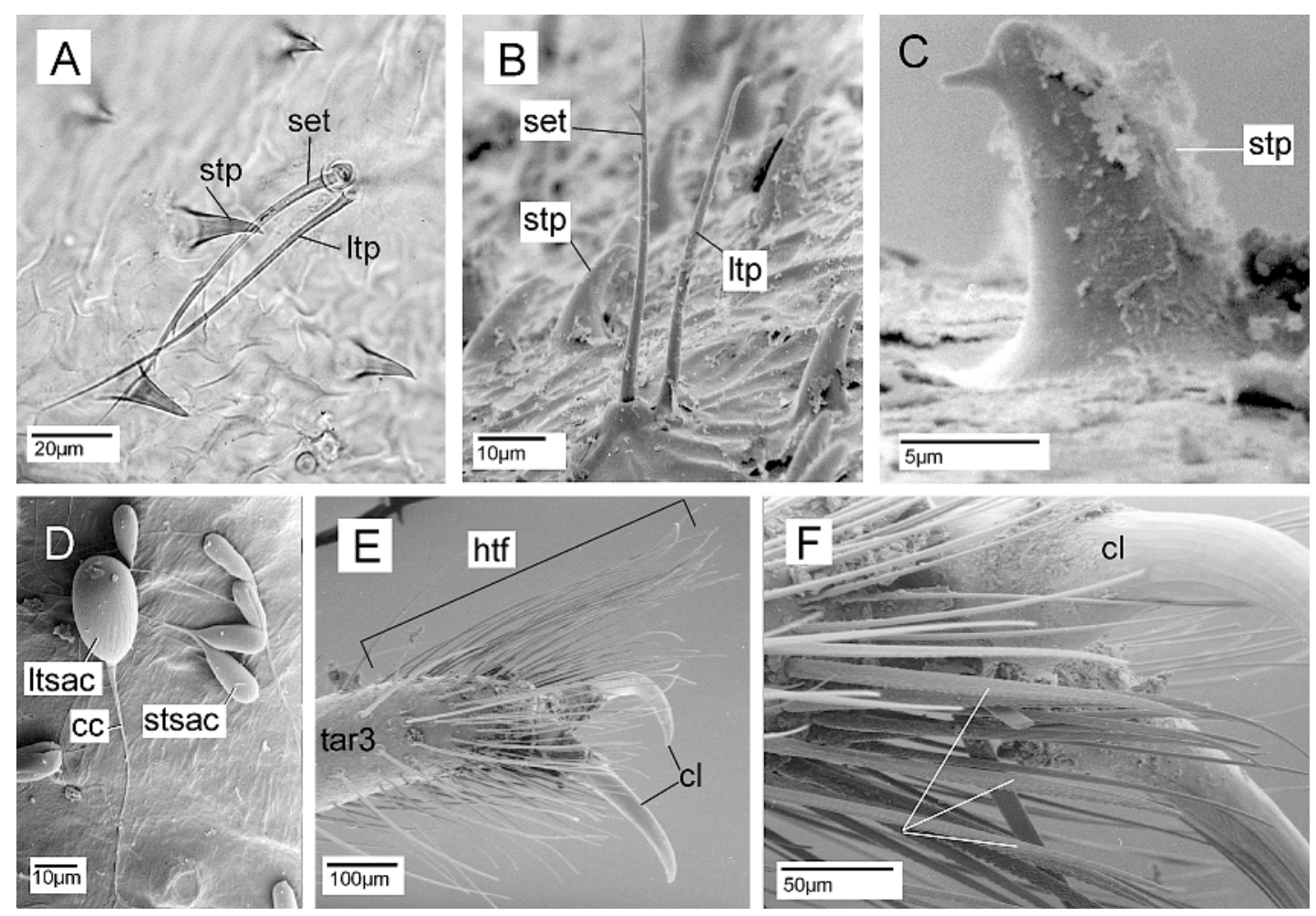

Fig. 6. Reduvius personatus (Reduviinae): Camouflaging structures on the abdominal tergites in the fourth instar nymph, external views with exception of D (internal view). A. Hairlike long-projection trichome associated with one seta and several short-projection trichomes, LM. B. Hairlike long-projection trichome associated with one seta and several short-projection trichomes, SEM. C. Short-projection trichome. D. Ductules of long-projection trichomes and short-projection trichomes. E. Hind-tarsal fan. F. Setae with serrated ventral surface on ventral side of third tarsomere.

stricted to sclerotized patches not representing the sclerotizations associated with muscle attachments (figs. 1, 4A-C), but some trichomes also on the membranous parts of the abdominal tergites. No intimate association of long-projection trichome with single seta, but loose assemblage of trichomes and setae on sclerotized plates (fig. 4B, C).

Holotrichius tenebrosus (figs. 1, 2, 5A-C): Only one type of trichome on abdomen (fig. 5A), possibly representing short-projection trichomes; no grouped trichomes. Projections in the form of moderately elongate spines with blunt apices and with corresponding pear-shaped saccules $(1=40 \mu \mathrm{m})$ (fig. 2).

The situation in this species is not easily compared with that in other species, in which short projections co-occur with small saccules and long projections with large, elliptical saccules, since the relatively short projection in $H$. tenebrosus is associated with very large pear-shaped saccules. Primary homology assessment of the trichome in this species with the short-projection trichome in other species is thus tentative. Sometimes the trichome is associated with a single seta (fig. 5B).

Leogorrus sp. (figs. 1, 2, 5D, E): Short- and long-projection trichomes present on abdomen, no grouped trichomes (figs. 2, 5D, E). Short-projection trichome with slender and erect spines $(1=$ approximately $40 \mu \mathrm{m})$ and elliptical saccules $(1=$ approximately $12 \mu \mathrm{m})$. These projections abundant on the abdominal tergites. Long-projection trichomes very long and hairlike $(1=$ approximately $160 \mu \mathrm{m})$ and with elliptical saccules $(1=$ approximately $30 \mu \mathrm{m})$. These trichomes arranged in a transverse row in the posterior area of the tergite 


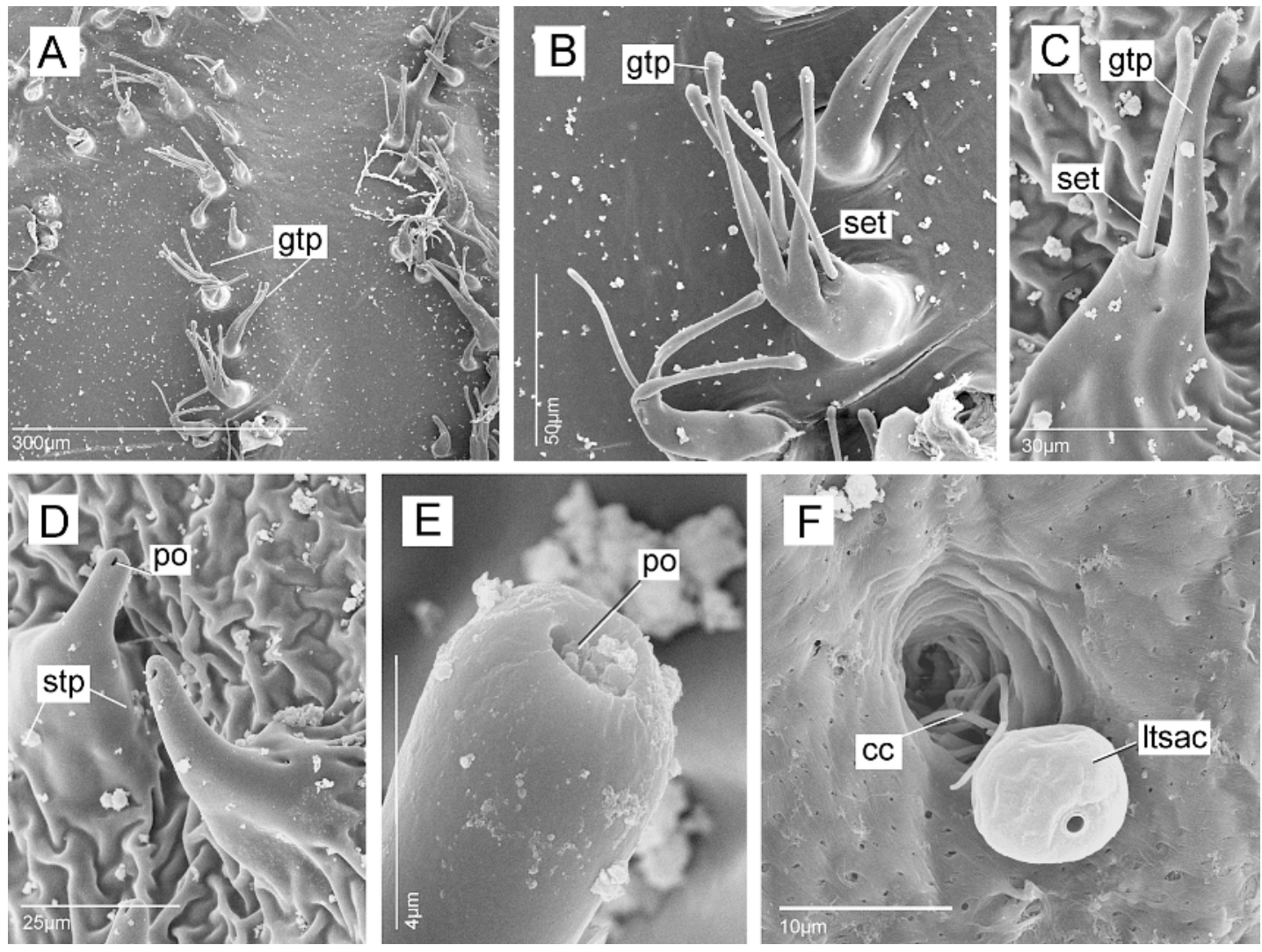

Fig. 7. Salyavata sp. (Salyavatinae): Camouflaging structures on pronotum and abdominal tergites in the 5th instar nymph, SEM, all external view with exception of F (internal view). A. Rows of grouped trichomes on the pronotum. B. Grouped trichome. C. Long-projection trichome with associated seta. D. Sort-projection trichomes. E. Apex of long-projection trichome with pore. F. Ductule of longprojection trichome.

(fig. 5E) and occurring in patches on the lateral sclerotization of the tergites (fig. 5D). No intimate association of long-projection trichome with individual seta, but loose assemblage of trichomes and setae on sclerotized plates (fig. 5D).

Reduvius personatus (figs. 1, 2, 6): Shortand long-projection trichomes present on abdomen, no grouped trichomes. Short-projection trichome thorn-shaped with pointed and curved tips $(1=$ approximately $20 \mu \mathrm{m})$ and with elliptical saccules $(1=$ approximately $10 \mu \mathrm{m}$ ) (figs. 2, 6A-D). These projections abundant on the abdominal tergites (fig. 6A). Long-projection trichomes hairlike $(1=$ approximately $150 \mu \mathrm{m}$ ) and with elliptical saccules $(1=$ approximately $50 \mu \mathrm{m})$ (figs. $6 \mathrm{~A}, \mathrm{~B}$, D). Long-projection trichomes sparsely dis- tributed on abdominal tergites. Long-projection trichomes usually closely associated with a single seta with few, fine branches (figs. 2, $6 \mathrm{~A}, \mathrm{~B})$.

Careful dismantling of the wood-dust layer on a living nymph showed that two layers of camouflaging may be distinguished: a layer of very fine wood dust closely adhered to the integument and a relatively coarser layer of wood and bark particles was attached further from the body.

Salyavata sp. (figs. 1, 2, 7, 8): Long-projection trichomes and short-projection trichomes on the abdomen, grouped trichomes predominantly on the thorax. Short-projection trichome spinelike $(1=$ approximately $30 \mu \mathrm{m})$, with saccules elliptical $(1=$ approximately $15 \mu \mathrm{m}$ ), sparsely distributed on the 


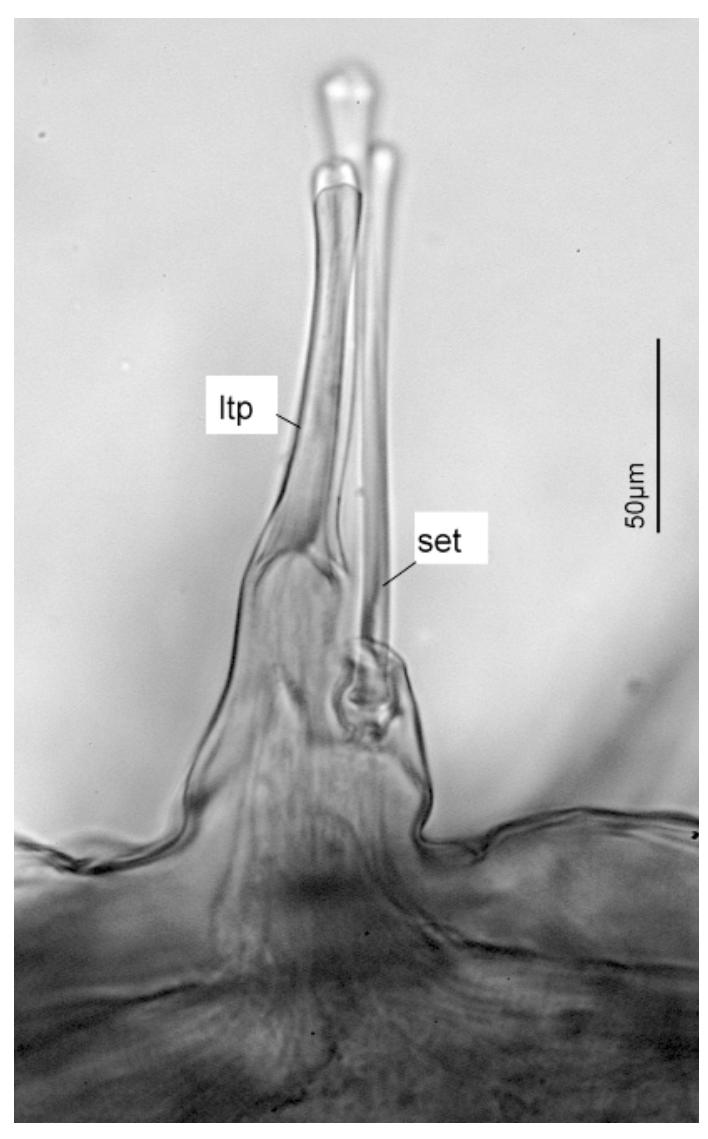

Fig. 8. Salyavata sp.: Long-projection trichome with associated seta, 5th instar nymph, LM.

abdomen (fig. 7D). Long-projection trichomes with hairlike projection $(1=$ approximately $100 \mu \mathrm{m})$ and elliptical saccules $(1=$ approximately $25 \mu \mathrm{m}$ length) (fig. 7C, F, 8). Longprojection trichomes rather sparsely distributed on the abdomen, mostly on the lateral margins of the abdominal tergites.

Trichomes on the thorax agree with above description of the long-projection trichomes, but occur in groups of two to seven trichomes (figs. 7A, B) and not as single trichomes. Long-projection trichomes and grouped trichomes are usually closely associated with one seta (figs. 2, 7B, C).

Sphaeridops sp. (figs. 1, 2, 9): No single trichomes, two types of grouped trichomes, the one on the thorax consisting of group of long-projection trichomes (figs. 9A-C), the one on the abdomen externally rosette-shaped (figs. 9D-F). Both grouped trichomes with saccules of approximately $25 \mu \mathrm{m}$ length.

Triatoma vitticeps (fig. 2): No trichomes on the abdomen, but saccules of approximately $10 \mu \mathrm{m}$ length occurring in low numbers on the membranous parts of the abdominal tergites.

\section{DISCUSSION}

The present study is the first comparative approach to the study of camouflaging structures in nymphs of Reduviidae and several structures associated with camouflaging are described here for the first time. Camouflaging structures in Reduviidae comprise a hind tarsal fan, which may assist in applying camouflaging material to the body, and two types of fastening structures, anchor setae and trichomes. Whereas the anchor setae presumably hold the camouflaging material mechanically, the trichomes probably secrete a sticky substance that attaches the particles to the insect. Among the trichomes observed, shortprojection trichomes are distinguishable from long-projection trichomes, and in two of the observed species trichomes are not always distinctly separated from each other but may form grouped trichomes.

Among the eleven species studied here, trichomes were not only found in the six species for which camouflaging had previously been described, but also in two species with unknown immature biology. The presence of camouflaging structures in these latter species suggests the presence of camouflaging behavior in nymphs of Eupheno sp. (Cetherinae) and Sphaeridops sp. (Sphaeridopinae).

Hind TARSAL FAN: The presence of long and fine setae on the hind tarsus, i.e., the hind tarsal fan, was previously described for nymphs of numerous species of Triatominae (Lent and Wygodzinsky, 1979). Zeledón et al. (1973) documented the presence or absence of camouflaging behavior for several species of Triatominae. However, presence or absence of the hind tarsal fan was never before discussed in combination with the presence or absence of camouflaging behavior in Triatominae. Table 2 shows that the presence of the hind tarsal fan correlates with the presence of camouflaging behavior in the eleven species for which both factors have been documented. 

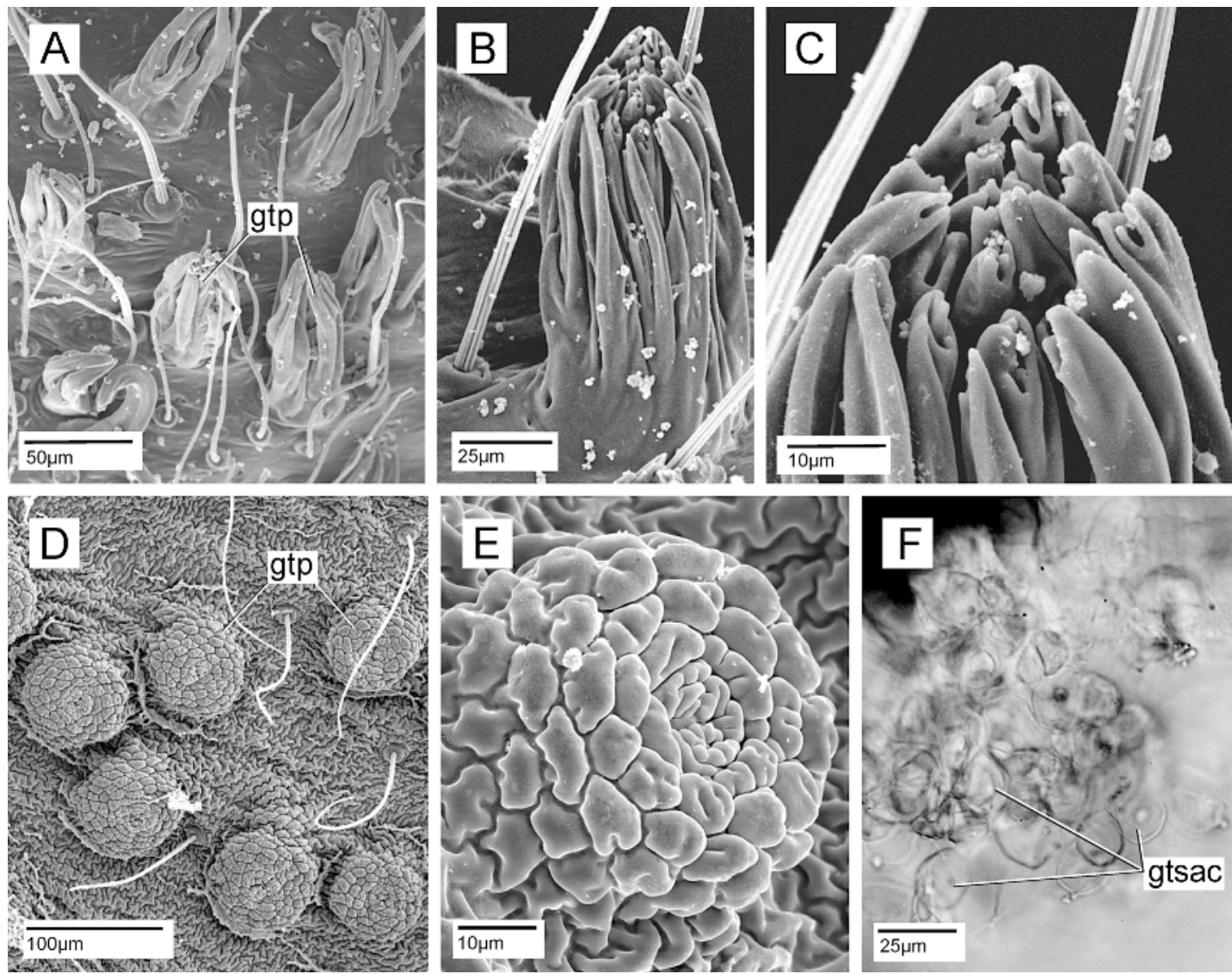

Fig. 9. Sphaeridops sp. (Sphaeridopinae): Camouflaging structures on pronotum and abdominal tergites in the 5th instar nymph, SEM, all external view with exception of F (internal view). A-C. Grouped trichomes on the pronotum. D, E. Rosettelike projection trichomes on the abdominal tergites. F. Saccules of the rosettelike projection trichomes seen in the light microscope.

Aside from this intriguing correlation, the hind legs were reported to play the central role in the process of gathering and loading camouflaging material onto the abdominal tergites in several species of Triatominae and other Reduviidae (McMahan 1982, Hase 1940, Louis 1974, Kott 2001, Weber 1930). The fan, which is formed by long, fine setae, most likely assists in this process. The hind tarsal fan is present also in several Reduviinae, Acanthaspis sp., Leogorrus, and Reduvius personatus, and is here proposed to have the same function as the hind tarsal fan in Triatominae. However, the application of camouflaging material must be possible without a hind tarsal fan, because the hind tarsal fan is absent in several species that are known to camouflage or show camouflaging structures, e.g., Eupheno sp. (Cetherinae), Holotrichius tenebrosus (Reduviinae), Salyavata sp. (Salyavatinae), and Sphaeridops sp. (Sphaeridopinae). Future observation of camouflaging behavior in these species and examination of substrate used for camouflage may help to explain why some species possess an application structure and other species lack it. Furthermore, the hind tarsal fans in Triatominae and some species of Reduviinae are not necessarily homologous structures, but may have independent origins. This question will be answered only through a cladistic analysis of Reduviidae.

Future research into systematic distribution and biological function of the serrated setae 


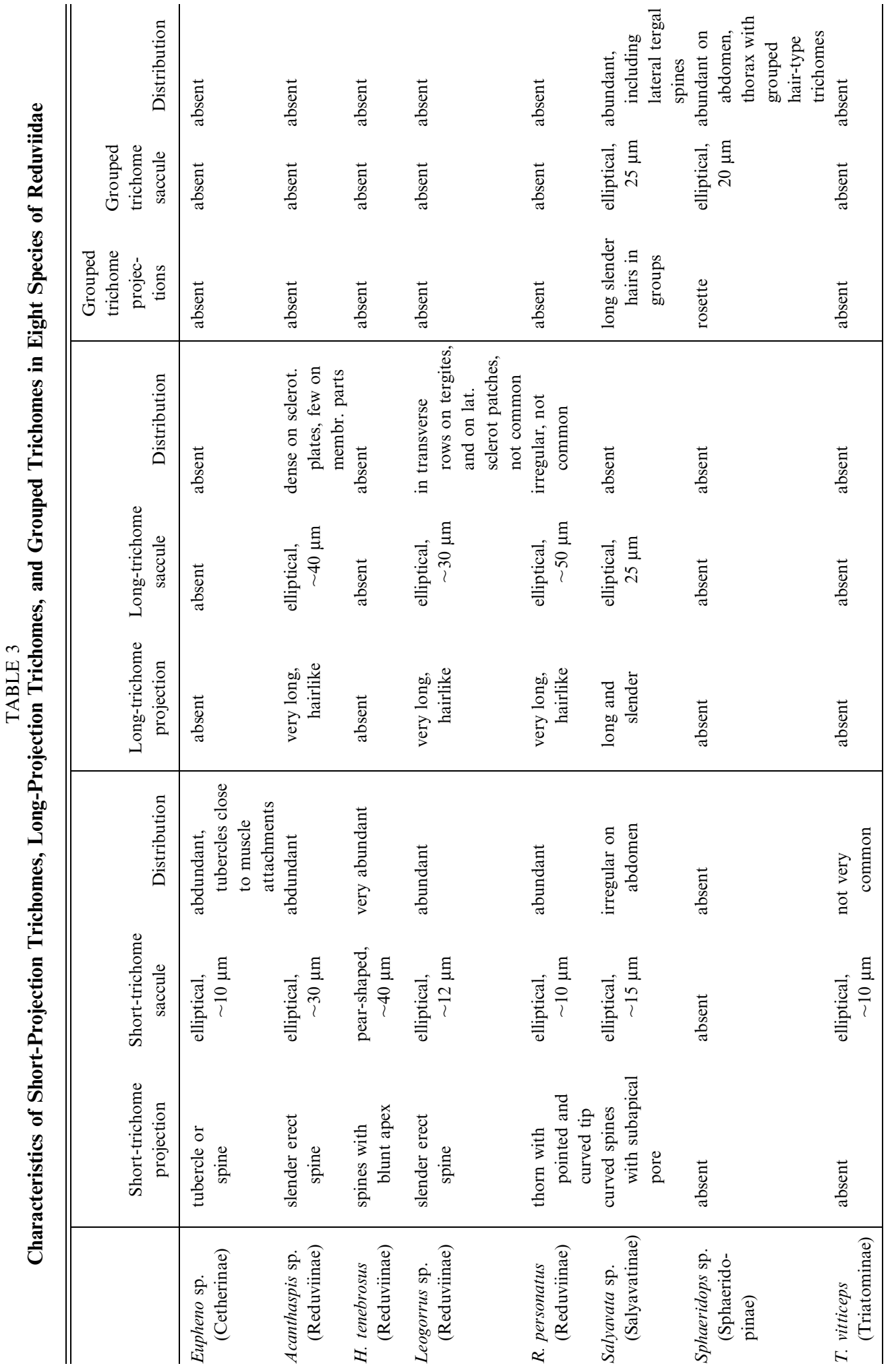


on the ventral surface of the distal tarsomere, which were here documented only for $R e$ duvius personatus (fig. 6F) and hypothesized to assist in loosening camouflaging particles from the substrate, could provide further insights into the process of camouflaging.

Anchor Seta: Among the eight examined species that have fastening structures, only the two specimens of Acanthaspis from South India and Myanmar were found to possess anchor setae. Possibly, therefore, anchor setae represent a unique feature of species of the genus Acanthaspis. Examination of additional species of Acanthaspis and other, possibly closely related taxa such as Paredocla and Edocla, will be necessary to test this hypothesis.

It may be worth noting that the very long and slender anchor setae occur in the only taxon examined for which corpse camouflage has been reported (Ambrose, 1999; Brand and Mahsberg, 2002; Louis, 1974; Odhiambo, 1958). Possibly the comparatively heavy and bulky corpse cover requires mechanical fastening in addition to the adhesion offered by the trichome secretions. Examination of the other two taxa for which corpse camouflage is known, Edocla (Ambrose, 1999) and Paredocla (Brand and Mahsberg, 2002), may provide additional evidence for this hypothesis.

Primary Homology of Short- AND LongProjection Trichomes: Given the comparative approach of this study, but the lack of understanding of relationships within Reduviidae, only tentative primary homology statements may be formulated for the trichomes. A distinction between short- and long-projection trichomes seems evident in those cases where both types of trichomes appear in one species, because the two types are clearly differentiated by the shape and length of the projections and the size of the saccules. Such clear distinctions are seen in three taxa of Reduviinae, Acanthaspis, Leogorrus, and Reduvius (table 3). In these three species, short-projection trichomes are of roughly similar size (projection and saccule) as are the long-projection trichomes. A primary homology statement for the short-projection trichomes as well as the long-projection trichomes among these taxa seems tenable.
Holotrichius tenebrosus is difficult to interpret in this context: only one type of trichome is present, which comprises relatively short, blunt, spinelike projections of approximately $20 \mu \mathrm{m}$ length which are sometimes associated with a seta, but which have very large saccules (approximately $30 \mu \mathrm{m}$ ). Considering the equal and rather dense distribution of the trichomes on the abdominal tergites, it appears reasonable to interpret them as short-projection trichomes. Examination of additional species of this genus may provide further insights.

With respect to size and shape of projection and saccule, the short-projection trichome in Eupheno (Cetherinae) and Salyavata (Salyavatinae) may be considered primary homologous to the short-projection trichomes in Reduviinae.

Potential Function of Short- and LongProjection Trichomes: Short- and longprojection trichomes and anchor setae may serve different functions: Brandt and Mahsberg (2002) found that two layers of camouflaging material are applied by Acanthaspis, consisting of a dust cover close to the integument, and a cover of corpses and other coarse material that is further removed from the body. Short-projection trichomes and long-projection trichomes plus anchor setae, respectively, may be responsible for these two layers. Brandt and Mahsberg (2002) could further demonstrate that the dust cover plays a role in aggressive mimicry, whereas the corpse cover seems to be important as protection from potential predators.

A two-layer camouflage is also present in Reduvius personatus, although in a less spectacular way. Examination of a living nymph during this project showed that one layer of camouflaging material consists of small particles that adhere very closely to the integument, whereas coarser substrate particles form a second layer that is further removed from the integument. Whether the two layers of this cover serve the same function as the layers in Acanthaspis remains open to speculation and further experimentation.

Seta Associated with Long-Projection Trichome: At least in some instances, the long-projection trichome is associated with a single, long, slender seta, which may be mechanosensory. This association is seen in 
Reduvius personatus, in which the seta is slightly plumose, in Salyavata sp., and also in the single type of trichome present in Holotrichius tenebrosus. In Acanthaspis and Leogorrus, long-projection trichomes are more loosely associated with setae on the sclerotized plates; setae are rather evenly distributed on the thorax and abdomen in Sphaeridops. Eupheno sp. lacks long-projection trichomes as well as setae in association with trichomes. Assuming that the setae close to the trichomes are in fact mechanoreceptive, they might provide information to the animal on its "loading status".

Grouped Trichomes in Salyavatinae AND SphaeridopinaE: Among the examined species, only Salyavata sp. (Salyavatinae) and Sphaeridops sp. (Sphaeridopinae) possess grouped trichomes. Given the length and shape of their projections and size of their saccules, these trichomes might be hypothesized as derived from long-projection trichomes that grouped together. Salyavata sp. possesses a combination of single long-projection trichomes and grouped trichomes with long projections. Sphaeridops, in contrast, possesses only grouped trichomes, which comprise trichomes with long projections on the thorax and rosette-shaped trichomes, i.e., trichomes whose exterior projections are extremely short, on the abdomen. The similar aspect of the grouped long-projection trichomes on the thorax of Salyavata sp. with those on the thorax in Sphaeridops sp. makes a hypothesis on primary homology of these structures reasonable. When it is also taken into account that Salyavatinae and Sphaeridopinae share several other morphological characteristics, such as highly modified mouthparts, unlike those seen in any species among Reduviidae, and similar structure of the antenna and female genitalia (personal obs., unpubl.), a closer relationship of these two taxa does appear likely. The rosette-shaped trichomes on the abdomen of Sphaeridops might then be derived from grouped long-projection trichomes of the type seen on the thorax in Sphaeridops and in Salyavata by a drastic shortening in those projections.

OuTLOOK: The present paper provides a first and albeit preliminary approach to the comparative study of camouflaging structures in Reduviidae. As more nymphs of
Reduviidae become available, the picture sketched in this paper will be improved considerably. Including camouflaging structures in a cladistic analysis of Reduviidae, currently in preparation, will test the homology of certain structures described here, such as the hind tarsal fan, the short- and longprojection trichomes, and the grouped trichomes in Salyavata and Sphaeridops. Finally, improved taxon sampling together with a cladistic analysis will shed light on where and how often camouflaging structures and therefore camouflaging behavior evolved within Reduviidae.

\section{ACKNOWLEDGEMENTS}

Randall Toby Schuh (AMNH) allowed me to study several immature specimens of Pedro Wygodzinsky's alcohol collection, and Ralf Britz, Peter Kott, and Walter Sudhaus kindly donated additional specimens studied during this project. To all these individuals a warm "thank you".

The results presented here are largely derived from my $\mathrm{PhD}$ dissertation, and were obtained while working at the Freie Universität Berlin and during a three-month visit to the AMNH. I thank Walter Sudhaus for supervising my dissertation and the AG Evolutionsbiologie for discussions. For financial support I would like to acknowledge the Nachwuchsförderungsgesetz des Landes Berlin (NaFöG), Anette Kade Graduate Student Fellowship Program at the AMNH, and the Berliner Programm zur Förderung der Chancengleichheit für Frauen in Forschung und Lehre.

Thanks also to Randall Toby Schuh and Dimitri Forero for kindly commenting on the manuscript.

\section{REFERENCES}

Ambrose, D.P. 1999. Assassin bugs. Enfield: Science Publishers, 337 pp.

Brandt, M., and D. Mahsberg. 2002. Bugs with a backpack: the function of nymphal camouflage in the West African assassin bugs Paredocla and Acanthuaspis spp. Animal Behaviour 63: 277-284. 
Breddin, G. 1904. Rhynchoten aus Ameisen- und Termitenbauten. Annales de la Société Entomologique Belge 48: 407-416.

Butler, E.A. 1923. A biology of the British Hemiptera-Heteroptera. London: H. F. \& G. Witherby, 682 pp.

Cai, W., P. Zhao, and Q. Mi. 2002. Camouflaging in assassin bugs. Entomological Knowledge 39: 317-319. [In Chinese, English summary]

Dispons, P. 1955. Les Réduviidés de l'Afrique nordoccidentale. Mémoires du Muséum National d'Histoire Naturelle, Nouvelle Serie Série A Zoologie 10: 93-240.

Eisner, T., K. Hicks, and D.S. Robson. 1978. Wolfin-sheep's-clothing strategy of a predacious insect larva. Science 199(4330): 790-794.

Fabre, J.-H. 1903. Souvenirs entomologiques. 8e série. VI. Le Réduve à masque. Paris, 380 pp.

Fabricius, J.C. 1775. Systema entomologiae, sistens insectorum classes, ordines, genera, species, adjectis synonymis, locis, descriptionibus, et observationibus. Kortii: Flensburgi \& Lipsiae, i-xxx, $832 \mathrm{pp}$.

Farine, J.-P. 1987. The exocrine glands of Dysdercus cingulatus (Heteroptera, Pyrrhocoridae): morphology and function of the nymphal glands. Journal of Morphology 194: 195-207.

Harz, K. 1952. Ein Beitrag zur Biologie von Reduvius personatus L. (Rynchita [sic!]/ Heteroptera). Nachrichtenblatt der Bayerischen Entomologen 1(10): 73-75.

Hase, A. 1940. Über Triatoma dimidiata (Hemiptera, Triatomidae). I. Teil. Zeitschrift fuer Parasitenkunde 11: 419-429.

Immel, R. 1955. Zur Biologie und Physiologie von Reduvius personatus L. Zeitschrift fuer Morphologie und Oekologie der Tiere 44: 163-195.

Kott, P. 2001. Holotrichius tenbrosus Burmeister, 1835 (Hemiptera): Beobachtungen zur Maskierung der Larven. Verhandlungen des Westdeutschen Entomologen Tags 2000: 229-232.

Lent, H., and P. Wygodzinsky. 1979. Revision of the Triatominae (Hemiptera, Reduviidae), and their significance as vectors of Chagas' disease. Bulletin of the American Museum of Natural History 163: 123-520.

Linnaeus, C. 1758. Systema naturae per regna tria naturae, secundum classes, ordines, genera, species, cum characteribus, differentiis, synonymis, locis. Editio decima, reformata. Salvii: Holmiae, i-v, 824 pp.
Louis, D. 1974. Biology of Reduviidae of cocoa farms in Ghana. American Midland Naturalist 91: 68-89.

Madel, W. 1951. Beobachtungen an der Staubwanze Reduvius personatus L. Zeitschrift fuer Parasitenkunde 15: 102-108.

McMahan, E.A. 1982. Bait-and-capture strategy of a termite-eating assassin bug. Insectes Sociaux 29: 346-351.

McMahan, E.A. 1983a. Bugs angle for termites. Natural History 83: 40-46.

McMahan, E.A. 1983b. Adaptations, feeding preferences, and biometrics of a termite-baiting assassin bug (Hemiptera: Reduviidae). Annals of the Entomological Society of America 76: $483-486$.

Miller, N.C.E. 1953. Notes on the biology of the Reduviidae of Southern Rhodesia. Transactions of the Zoological Society of London 27: 541-672.

Miller, N.C.E. 1956. Biology of the Heteroptera. London: Leonard Hill Books, 162 pp.

Nichols, S.W. 1989. The Torre-Bueno glossary of entomology. New York: Entomological Society, $840 \mathrm{pp}$.

Noirot, C., and A. Quennedey. 1991. Glands, gland cells, glandular units: some comments on terminology and classification. Annales de la Société Entomologique de France 27: 123-128.

Odhiambo, T.R. 1958. The camouflaging habits of Acanthaspis petax Stål (Hem., Reduviidae) in Uganda. Entomologist's Monthly Magazine 94: 47.

Readio, P.A. 1927. Studies on the biology of the Reduviidae of America north of Mexico. University of Kansas Science Bulletin 17: 5-291.

Stitz, H. 1931. Planipennia. In P. Schulze (editor), Biologie der Tiere Deutschlands. Teil, 35: 68-304. Berlin: Borntraeger.

Villiers, A. 1948. Faune de l'empire français. IX. Hémiptères Réduviides de l'Afrique noire. Paris: Edition du Muséum, 488 pp.

Weber, H. 1930. Biologie der Hemipteren. Berlin: Julius Springer, 543 pp.

Wygodzinsky, P., and R.L. Usinger. 1946. The genus Reduvius Fabricius in western North America (Reduviidae, Hemiptera, Insecta). American Museum Novitates 2175: 1-15.

Zeledón, R., C.E. Valerio, and J.E. Valerio. 1973. The camouflage phenomenon in several species of Triatominae (Hemiptera, Reduviidae). Journal of Medical Entomology 10: 209-211. 